\title{
Local treatment of pain in Tietze syndrome: A single-center experience
}

\author{
Tietze sendromunda lokal ağrı tedavisi: Tek merkez deneyimi

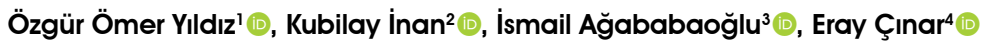 \\ Institution where the research was done: \\ Yildirm Beyazit University, Faculty of Medicine, Ankara, Turkey \\ Author Affiliations: \\ 'Department of Thoracic Surgery, Yildirım Beyazit University, Faculty of Medicine, Ankara, Turkey \\ ${ }^{2}$ Department of Thoracic Surgery, Ankara City Hospital, Ankara, Turkey \\ ${ }^{3}$ Department of Thoracic Surgery, YIldırm Beyazit University, Yenimahalle Training and Research Hospital, Ankara, Turkey \\ ${ }^{4}$ General Directorate of Emergency Medical Services, Republic of Turkey, Ministry of Health, Ankara, Turkey
}

\begin{abstract}
Background: In this study, we present our experiences with local injections of triamcinolone and prilocaine in patients diagnosed with Tietze syndrome.

Methods: Between January 2016 and January 2019, a total of 28 patients (12 males, 16 females; median age: 33 years; range, 21 to 51 years) who were diagnosed with TS in our clinic were retrospectively analyzed. Triamcinolone hexacetonide and prilocaine hydrochloride were injected into painful joints. At first week, pain sensation of the patients was recorded using the Pain Rating Scale developed by the British Pain Society. Pain was also assessed at one, two, and three weeks after injections qualitatively and based on physical examination.
\end{abstract}

Results: At one week, the pain severity before the local injection treatment was above average the pain-related discomfort rates, and the response was quite favorable after the treatment $(\mathrm{p}=0.005$ and $\mathrm{p}=0.001$, respectively). A statistically significant rating was observed for treatment response and success $(\mathrm{p}=0.003)$. Totally $75 \%$ of the patients experienced more than $70 \%$ reduction in pain level after the injection.

Conclusion: Our treatment approach involving injection of a mixture of steroid and a local anesthetic provides a rapid relief from pain, irrespective of age, sex, or employment status in patients diagnosed with Tietze syndrome.

Keywords: Arthralgia, chest pain, Tietze syndrome.

\section{$\ddot{O} Z$}

Amaç: Bu çalışmada, Tietze sendromu tanısı konulan hastalarda, lokal triamsinolon ve prilokain enjeksiyonları ile ilgili deneyimlerimiz sunuldu.

Çalışma planı: Ocak 2016 - Ocak 2019 tarihleri arasında, kliniğimizde Tietze sendromu tanısı konulan toplam 28 hasta (12 erkek, 16 kadın; medyan yaş: 33 yıl; dağılım, 21-51 yıl) retrospektif olarak incelendi. Ağrılı eklemlere triamsinolon heksasetonid ve prilokain hidroklorür enjeksiyonları yapıldı. Hastaların ağrı duyumları birinci haftada İngiliz Ağrı Derneği tarafından geliştirilen Ağrı Derecelendirme Ölçeği ile kaydedildi. Enjeksiyondan sonra bir, iki ve üçüncü haftalarda da ağrı kalitatif olarak ve fizik muayene ile değerlendirildi.

Bulgular: Birinci haftada lokal enjeksiyon tedavisi öncesi ağrı şiddeti, ağrıya bağlı ortalama rahatsızlık oranlarının üzerinde iken, tedavi sonrası yanıt oldukça iyi idi (sırasıyla, $\mathrm{p}=0.005$ ve $\mathrm{p}=0.001)$. Tedavi yanıtı ve başarısının genel derecelendirmede istatistiksel olarak anlamlı olduğu gözlendi $(\mathrm{p}=0.003)$. Hastaların toplam \%75'inde enjeksiyon sonrası ağrı düzeyinde \%70'den fazla azalma görüldü.

Sonuç: Steroid ve lokal anestezik enjeksiyonunu içeren tedavi yaklaşımımız, Tietze sendromu tanısı konulan hastaların yaş, cinsiyet veya istihdam durumundan bağımsız olarak, ağrıdan hızlı bir şekilde kurtulmalarını sağlar.

Anahtar sözcükler: Artralji, göğüs ağrısı, Tietze sendromu.

Received: November 19, 2020 Accepted: December 29, 2020 Published online: April 26, 2021

Correspondence: Özgür Ömer Yıldız, MD. Yıldırım Beyazıt Üniversitesi Tıp Fakültesi Göğüs Cerrahisi Anabilim Dalı, 06800 Çankaya, Ankara, Türkiye. Tel: +90 533 - 8147314 e-mail: dr.ooyildiz@gmail.com 
Tietze syndrome (TS) is a rare, non-suppurative disease, which is characterized by tenderness and pain in parasternal regions. ${ }^{[1]}$ Functional overloading or microtrauma, sprain of the intra-articular sternocostal ligament and prior respiratory tract infections have been implicated in its etiology. It is reported with an incidence of $10 \%$ in the general population. ${ }^{[2,3]}$ Differential diagnosis of TS includes a variety of emergency pathologies and chest wall tumors. Patients with chest pain often present to cardiology clinics and emergency departments and, therefore, a diagnosis of TS may be delayed..$^{[4]}$

Controversy exists about the diagnostic process and treatment modalities for TS which mostly involves costochondral, costosternal and sternoclavicular joints on one side, and the second or third costochondral junction is frequently affected..$^{[5]}$ Therapeutic options for TS include conservative treatment with non-steroidal anti-inflammatory drug (NSAID) therapies and avoiding movements that cause pain, as well as intercostal blockade, local lidocaine infiltration, and surgical resection of the affected joint.

In the present study, we aimed to present our experience with local injections of triamcinolone and prilocaine in patients diagnosed with TS for which different treatment alternatives exist, but therapeutic response is usually low.

\section{PATIENTS AND METHODS}

This single-center, retrospective study was conducted at thoracic surgery clinic of Yıldırım Beyazıt University, Faculty of Medicine between January 2016 and January 2019. A total of 28 patients (12 males, 16 females; median age: 33 years; range, 21 to 51 years) admitted to our clinic with complaints of swelling and pain in one or more sternoclavicular, sternocostal, and costochondral joints and who were diagnosed with TS were included. A written informed consent was obtained from each patient. The study protocol was approved by the Ankara City Hospital Ethics Committee (Date: 28/05/2020-No: E1-20-706). The study was conducted in accordance with the principles of the Declaration of Helsinki.

A detailed medical history and physical examination findings were reviewed and laboratory parameters were recorded. The initial conventional chest X-rays and, then, thoracic computed tomography (CT) scans which were interpreted by a blinded radiologist were reviewed. All patients underwent electrocardiography (ECG) tracings to exclude cardiac pathologies and a cardiologist was consulted. The patients diagnosed with TS who had no other pathologies or abnormalities on imaging studies were given injections of triamcinolone hexacetonide $(20 \mathrm{mg} / \mathrm{mL})$ and prilocaine hydrochloride ( $\mathrm{HCl})(20 \mathrm{mg} / \mathrm{mL})$ into the painful joints. Administered doses of the medications were $1 \mathrm{~mL}$ of triamcinolone hexacetonide and $2 \mathrm{~mL}$ of prilocaine $\mathrm{HCl}$ for each painful joint. The injections were given to patients in an intervention room where all the equipment and medical supplies were available. $1 \mathrm{~mL}$ of triamcinolone hexacetonide suspension for injection was administered in combination with $2 \mathrm{~mL}$ of prilocaine into each involved joint as the corticosteroid derivative and was preferred in the current study, as it is less soluble compared to other steroid derivatives and remains longer in the joint. ${ }^{[6]}$ Local injections were administered into and around the joints including the $0.5-\mathrm{cm}$ area around the joints at $0.2-\mathrm{cm}$ intervals by palpation. Repeated chest radiographs were obtained from all patients. Patient's body weight was not taken into account, as the drug dose was determined according to the area to be applied in local injections.

All patients were asked to return for a follow-up visit one week later and, then, for subsequent visits in a three-month period. The effectiveness of the drugs applied is known to start in a short time. However, the first check-up started after one week to assess their long-term effectiveness. At the first week, pain sensation of the patients was recorded using the Pain Rating Scale (PRS) developed by the British Pain Society (BPS) (2006/Charity No. 1103260, Turkish and English version). Pain was also assessed at one, two, and three weeks qualitatively and based on physical examination. The PRS was used to assess pain severity, distress caused by pain and interference of pain with daily activities on a $0-10$ scale before and after treatment. In this scale, 0 indicates no pain/distress/ interference and 10 indicates extreme pain/distress and complete interference. The ratings were recorded and the patients were asked to rate how much the treatment relieved their pain on a $0-100 \%$ scale (Appendix 1).

\section{Statistical analysis}

Statistical analysis was performed using the IBM SPSS for Windows version 23.0 software (IBM Corp., Armonk, NY, USA). The normality of variables was tested using the Shapiro-Wilks test. Continuous variables were expressed in mean \pm standard deviation or median (min-max), while categorical variables were expressed in number and frequency. The Kruskal-Wallis and Mann-Whitney U nonparametric tests were used to compare means of two and/or more independent samples and the Wilcoxon signed-rank test was used to compare means of two dependent samples. Analysis of variance was used 
for normally distributed variables. The correlation analysis was carried out to evaluate the strength of relationships between variables. A multidimensional scaling was used to visualize the level of similarity of pain sensation among patients. A $p$ value of $<0.05$ was considered statistically significant.

\section{RESULTS}

There were $11(39.3 \%)$ patients in the 20 to 30 age range, $12(42.9 \%)$ patients in the 31 to 40 age range, and five $(17.9 \%)$ patients aged $\geq 41$ years. The most common complaints were swelling and pain of sternoclavicular/costochondral joint (100\%), restricted movements in the arm on the affected side (28.6\%), and increased local temperature and redness (3.6\%). Eight patients had both restricted movements and pain. Aggravation of pain with movements of the arm on the affected side and body movements was noted for all patients. Thoracic CT scan and posteroanterior chest radiography were performed for all patients. Images were evaluated by the radiologist and our clinical staff, and no pathological findings were detected. In addition, laboratory work-up of the patients showed no significant pathologies. None of the patients had a history of trauma, assault or falls within the past three months. However, all patients received medical treatment at different clinics.

Pain sensation was present in the right second and third costochondral junctions in $16(57.1 \%)$ patients, left second and third costochondral junctions in six
(21.4\%) patients, right third costochondral junction in three $(10.7 \%)$ patients, right sternoclavicular joint in two $(7.1 \%)$ patients and right second, third, and fourth costochondral junctions in one (3.6\%) patient. The right arm was dominant. Nineteen patients were actively working, while nine were unemployed. All patients overloaded their sternocostal and costochondral joints while working or during leisure activities (Table 1).

Twenty-eight patients diagnosed with TS received medical therapy for at least three weeks with no improvement and were informed about injection therapy to be administered into each affected joint for local pain control. None of the patients developed an infection or complications after treatment.

At one-week assessment, the rate of patients with a rating greater than 5 on pain intensity and distress from pain decreased after local injection therapy versus baseline using the PRS, indicating a very good therapeutic response $(p=0.005$ and $p=0.001$, respectively). While interference of pain with everyday activities is assessed by the PRS using a single question, we evaluated this by asking two separate questions (last week and current). A marked reduction was observed in the interference of pain with everyday activities after treatment $(\mathrm{p}<0.05)$ (Table 2$)$. The rating of interference of pain of the patients with daily activities currently was significantly less than last week.

When the responses to the question concerning the extent of pain relief after the treatment were

Table 1. Profession and employment status of Tietze syndrome patients

\begin{tabular}{lccc}
\hline Profession & $\mathrm{n}$ & Rate $(\%)$ & Active employment status \\
\hline Sports trainer & 1 & 3.6 & Employed \\
Computer service technician & 1 & 3.6 & Employed \\
Housewife & 4 & 14.3 & Unemployed \\
Photographer & 1 & 3.6 & Employed \\
Waiter & 2 & 7.1 & Employed \\
Construction engineer & 1 & 3.6 & Employed \\
Cargo delivery person & 1 & 3.6 & Employed \\
Officer (deskwork) & 7 & 25 & Employed \\
Student & 5 & 17.9 & Unemployed \\
Teacher & 3 & 10.7 & Employed \\
Mail carrier (e.g. carrying letters, documents) & 1 & 3.6 & Employed \\
Phone repair person & 1 & 3.6 & Employed \\
Total & 28 & 100 & 19 (67.9\%) Employed \\
& & & 9 (32.1\%) Unemployed \\
\hline
\end{tabular}




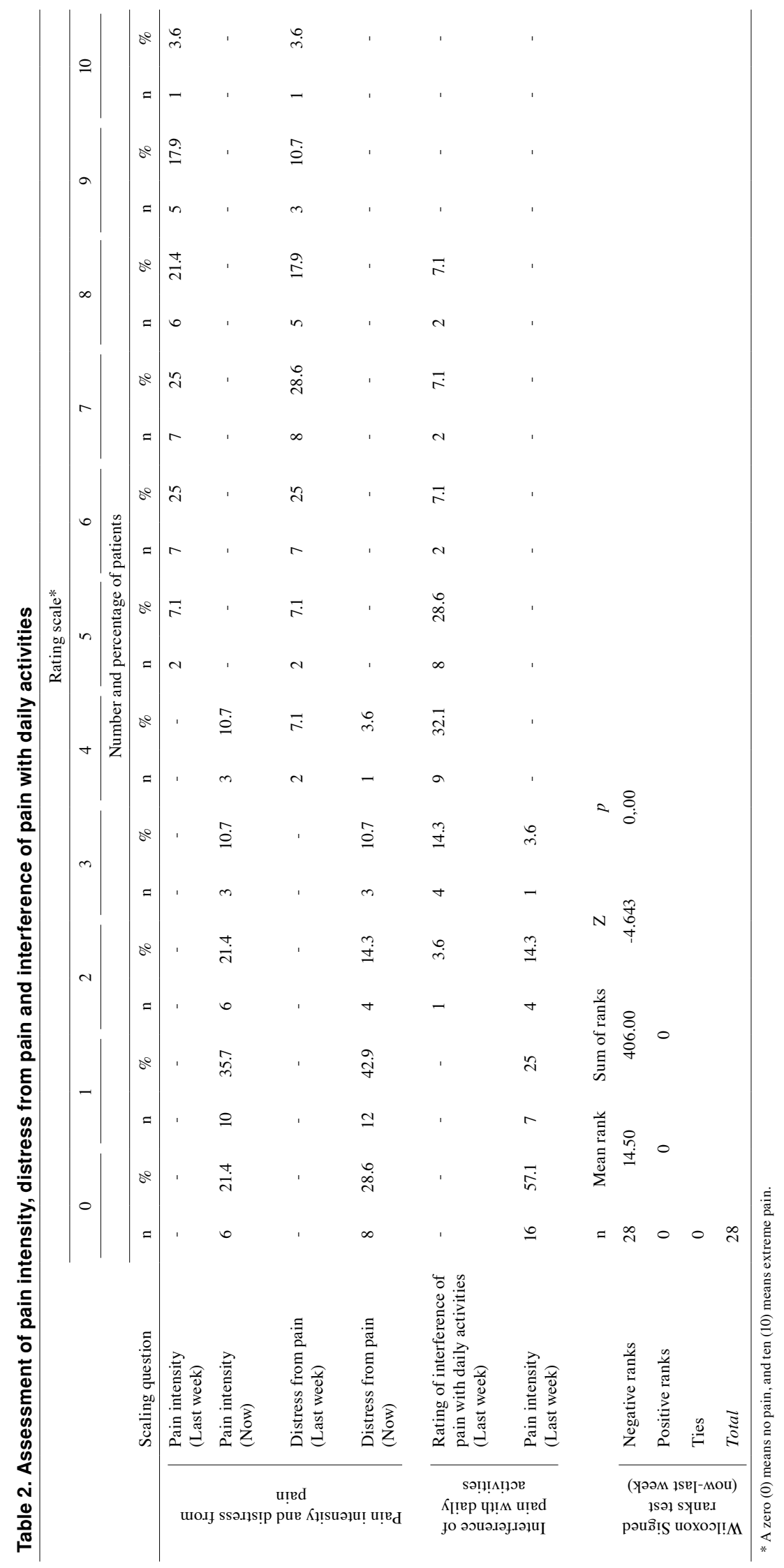


Table 3. Assessment of the extent of pain relief after treatment

Scaling question: If you have had treatment for your pain, how much has this relieved (taken away) the pain?

\begin{tabular}{ccc}
\hline Response $(\%)$ & Number of patients & Percentage \\
\hline 40 & 1 & 3.6 \\
50 & 2 & 7.1 \\
60 & 4 & 14.3 \\
70 & 1 & 3.6 \\
80 & 5 & 17.9 \\
90 & 9 & 32.1 \\
100 & 6 & 21.4 \\
\hline
\end{tabular}

examined, $75 \%$ of the patients were found to experience more than $70 \%$ reduction in pain after the injection, indicating a statistically significantly favorable rating $(\mathrm{p}=0.003)$ (Table 3$)$.

The responses on the PRS were analyzed based on age of the patient. No statistically significant differences were found among the different age groups. The best treatment response was observed in the 31 to 40 age group, although the difference was not statistically significant $(\mathrm{p}>0.05)$. The patients' responses on the PRS were also identified based on sex. There were no significant sex-related differences in pain sensation. While female patients responded better to treatment versus males, the difference was not statistically significant $(\mathrm{p}>0.05)$. Furthermore, the responses on the PRS were examined based on the employment status. Unemployed patients showed a better treatment response, although it did not reach statistical significance $(p>0.05)$. The correlation between the reduction in pain sensation and intensity after local treatment was found to be 0.934 , indicating statistical significance $(\mathrm{p}<0.05)$.

Pain reduction after the administration of study treatment was also analyzed using the multidimensional scaling method, which is a dimension reduction method showing a graphical view of all variables in the study and providing a better understanding of relations among them. In this method, there are two dimensions and each dimension represents a different factor. A very good therapeutic response was observed as shown in Figure 1. The treatment was evaluated according to the responses given to the pain sensations. The responses show us that patients experience good relief after treatment.

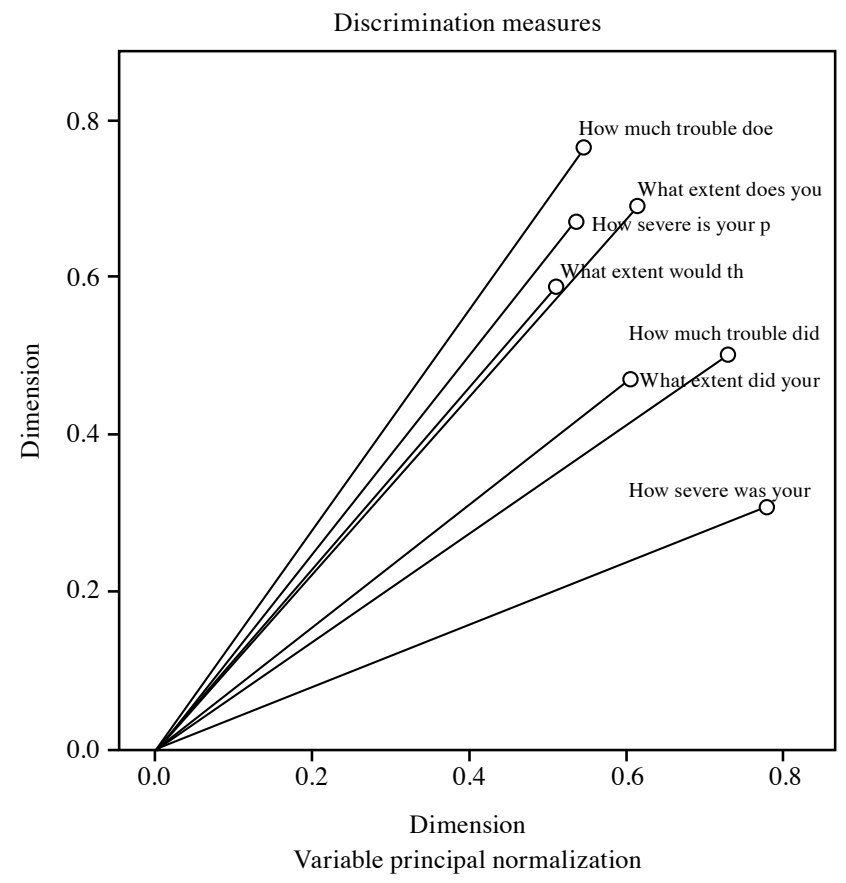

Figure 1. Visual representation of the responses and correlation analysis on multidimensional scaling.

The median follow-up was 122 (range, 90 to 270) days. A statistically significant therapeutic success and improved well-being observed at one week of follow-up were sustained at two and three months. At the end of the follow-up, a significant treatment response was observed.

\section{DISCUSSION}

Tietze syndrome was first described in 1921 by Tietze. ${ }^{[7]}$ It affects costochondral, costosternal, and xiphosternal joints unilaterally in $80 \%$ of the patients. ${ }^{[5]}$ In our study, unilateral involvement was observed in all patients (100\%), and pain was present in the right side in $22(78.6 \%)$ patients in the left side in six (21.4\%) patients. Several studies have reported that involvement of the second or third costochondral joint is seen in all age groups, but occurs more frequently in the second and third decades of life. ${ }^{[2,8]}$ Consistently, TS was most common in the second and third decades of life in our study (i.e., 20 to 40 age group, $82.2 \%$ ). All patients had complaints of swelling and pain in the sternoclavicular or costochondral joint. Increased local temperature, redness, and restricted movements of the arm on the affected side were observed less commonly. While the pain associated with TS has been described as a pain that radiates to the shoulder, arm and neck, it is often confined to the dermatome innervated by the affected 
segment. ${ }^{[9]}$ The pain associated with TS aggravates with movements of the chest wall, sneezing, coughing, deep breathing or bending. ${ }^{[10]}$ Similarly, increased pain with movement was observed in the present study. In general, TS affects women more often than men. ${ }^{[1,12]}$ Our study sample consisted of $12(42.9 \%)$ males and $16(57.1 \%)$ females and no significant difference was found in the sex distribution.

Conventional chest X-rays followed by CT and MRI can be used for the diagnosis of TS. ${ }^{[13]}$ In the study of Yang et al., ${ }^{[14]}$ although conventional radiographs could show enlargement of the costochondral junction, chondral calcification and irregular junction, these findings were not found to be specific. Thoracic CT can be also performed for differential diagnoses. ${ }^{[15]}$ All of our patients underwent diagnostic imaging studies which did not reveal any pathological findings.

The etiology of TS includes manual work that overloads the shoulder joints. ${ }^{[16]}$ Inflammatory conditions involving the joints and mechanical factors leading to microtrauma have been implicated.$^{[17]}$ When the distribution of TS by the employment status was analyzed for the study patients $(n=19$ currently working and $n=9$ unemployed), all of them were found to overload their joints. While this syndrome usually involves one side of the body, Zaruba et al. ${ }^{[18]}$ reported that the affected side was the dominant side of the patient. In all patients, the dominant arm was on the right side; however, in six patients (21.4\%), we diagnosed TS on the left side.

The diagnosis of TS is mainly based on the patient's history and physical examination findings. Mild swelling of the involved side can be noted. An increase in the local temperature may occur in the absence of signs of a systemic infection. Elevated erythrocyte sedimentation rate can be detected in some patients, although this is not specific. ${ }^{[3]}$

Currently, specific treatment modalities have not been established for TS and symptomatic treatment approaches are usually followed..$^{[3,19]}$ Management of TS includes avoiding movements that cause pain, conservative treatment with analgesics and NSAIDs, as well as intercostal nerve blockade, local injections of anesthetics or steroids and surgical excision. ${ }^{[20]}$

Persistence of pain for an extended period of time, despite the use of conservative treatments, disadvantages of NSAIDs and steroids, incomplete pain relief or recurrence of pain after surgery have prompted efforts to investigate other methods for the management of TS. It has been recently suggested that intra-articular injections of betamethasone and triamcinolone may be used for the treatment of TS based on the reports of their beneficial effects for knee osteoarthritis, particularly in orthopedic patients. ${ }^{[21,22]}$

There are also publications suggesting superiority of triamcinolone hexacetonide over betamethasone. ${ }^{[23,24]}$ Local anesthetics contribute to pain reduction and enhance dispersion of steroid into the joint due to volume effect. ${ }^{[25]}$ Triamcinolone hexacetonide resides within the joint for a long time owing to its lower solubility in the joint fluid and is more effective than other steroids. ${ }^{[26]}$ In one study, Bayrak et al. ${ }^{[6]}$ used triamcinolone hexacetonide in combination with prilocaine $\mathrm{HCl}$. A dramatic reduction in pain within the first $24 \mathrm{~h}$ with sustained efficacy up to four to eight was also previously reported. ${ }^{[27]}$ Repeated injections can be administered, if the pain recurs; however, they may cause adverse effects on the joint cartilage. ${ }^{[28]}$

The review of the literature reveals that the time to pain relief is about up to three weeks in patients treated with NSAIDs. ${ }^{[21]}$ In the current study, all of the patients diagnosed with TS previously received medical therapy for three weeks or longer. The patients whose pain did not resolve despite medical therapy were administered $1 \mathrm{~mL}$ of triamcinolone hexacetonide $(20 \mathrm{mg} / \mathrm{mL})$ in combination with $2 \mathrm{~mL}$ of prilocaine $(20 \mathrm{mg} / \mathrm{mL})$ into each affected joint. We clinically observed that this combination was effective in reducing pain from Day 1 . The treatment also showed a clinically significant permanent efficacy in the first week. Clinical improvement and $\geq 50 \%$ reduction in pain were observed in $96.4 \%$ of the patients with local injection treatment within one week. Therefore, our study has unique design, since none of the previous TS treatment studies used a similar methodology.

Local steroid injection delivers favorable results in patients with TS. It provides relief from local pain and swelling. This treatment can be safely administered under a strict aseptic technique. ${ }^{[29]}$

Surgery is another option for the treatment of TS patients; however, the lack of a defined surgical procedure, unsatisfactory rates of symptom relief after surgery, and the need for prosthesis after surgery in certain cases cause reluctance among patients to undergo surgery. In a case report published by Gologorsky et al., ${ }^{[30]}$ a surgical technique was described for the management of TS. However, we do not agree that is an effective treatment option, due to the lack of limited data. 
In Sentürk et al.'s ${ }^{[20]}$ study, patients with TS were divided into two groups: one group underwent conservative therapy with analgesics, while the other group underwent prolotherapy and a rapid clinical improvement was achieved with intra-articular injection of a mixture of $8 \mathrm{~mL} 20 \%$ dextrose and $2 \mathrm{~mL} \mathrm{2 \%} \mathrm{lidocaine.} \mathrm{In} \mathrm{a} \mathrm{recent} \mathrm{study,} \mathrm{Deyle} \mathrm{et} \mathrm{al.}{ }^{[31]}$ reported that orthopedists administered a mixture of $1 \mathrm{~mL}$ of $40 \mathrm{mg} / \mathrm{mL}$ triamcinolone acetonide admixed with $7 \mathrm{~mL} 1 \%$ lidocaine by intra-articular injections as a standard local treatment. They reported that triamcinolone was safe. Based on these findings, we used triamcinolone in our study. Since we have used prilocaine and bupivacaine safely and effectively in the treatment of intercostal blockage for many years, we used prilocaine, instead of lidocaine, as a local anesthetic in our study. Similarly, the effectiveness of intercostal nerve blockage has been proven in the literature. ${ }^{[32]}$

Although intra-articular administration of steroids and derivatives has been shown to be associated with adverse effects on the joint cartilage, they are effective for symptom relief and have proven long-term safety, as demonstrated by several studies. ${ }^{[28,33]}$ Following intra-articular injections, the incidence of iatrogenic infection is $1 / 14$ to 15,000 , and rapid chondrocyte breakdown does not occur. ${ }^{[34]}$ In the present study, none of the patients developed an infection after injections into the joints. Complications were not encountered in our patients. Determining the injection site and depth is of utmost importance to minimize the complication rate. We recommend that thoracic surgeons should perform this procedure, due to their command of the regional anatomy and their ability to manage possible complications.

The main limitations of this study are its small sample size and lack of a control group. However, the differential diagnosis was meticulously made in our study and only patients with true Teitze syndrome were included and other causes of pain were excluded, which make the sample size relatively small.

In conclusion, our treatment approach involving intra-articular injection of a mixture of a steroid (triamcinolone hexacetonide) and a local anesthetic (prilocaine) provides a rapid relief from pain, irrespective of age, sex, or employment status in patients diagnosed with Tietze syndrome. Patients may remain asymptomatic and pain-free during followup. This method represents an effective treatment option for Tietze syndrome patients having no clinical improvement, despite receiving long-term medical therapy. Also, the absence of local infections or complications supports the feasibility of the treatment method. Based on the successful results we achieved in our study, we believe that it can be considered as the primary treatment method in Tietze syndrome, pioneering future studies that would investigate the benefit of such treatments.

\section{Declaration of conflicting interests}

The authors declared no conflicts of interest with respect to the authorship and/or publication of this article.

\section{Funding}

The authors received no financial support for the research and/or authorship of this article.

\section{REFERENCES}

1. Cho JY, Park D. Ultrasound-guided corticosteroid injection in a patient with Tietze syndrome combined with costochondral joint swelling. Am J Phys Med Rehabil 2019;98:e71-e73.

2. Waldman SD. Tietze's syndrome. In: Waldman SD, editor. Atlas of Common Pain Syndromes. Philadelphia: WB Saunders; 2002. p. 158-60.

3. Hiramuro-Shoji F, Wirth MA, Rockwood CA Jr. Atraumatic conditions of the sternoclavicular joint. J Shoulder Elbow Surg 2003;12:79-88.

4. Boran M, Boran E. Tietze syndrome and idiopathic costochondritis - treatment modalities, recurrence rates, seasonality. World Journal of Pharmaceutical Research 2017;6:76-85.

5. Aeschlimann A, Kahn MF. Tietze's syndrome: A critical review. Clin Exp Rheumatol 1990;8:407-12.

6. Bayrak A, Bayrak SK, Duramaz A, Sahan C, Büyükhatipoğlu A, Aslantaş FÇ. Intra-articular knee steroid injections efficiency in stage 3-4 gonarthrosis. Med J Bakirkoy 2018;14:372-6.

7. Tietze A. Über eine eigenartige häufung von fällen mit dystrophie der rippenknorpel. Berl Klin Wochenschr 1921;58:829-31.

8. Stochkendahl MJ, Christensen HW. Chest pain in focal musculoskeletal disorders. Med Clin North Am 2010;94:259-73.

9. Hanak JA. Tietze's syndrome. In: Frontera WR, Silver JK, Rizzo TD, editors. Essentials of physical medicine and rehabilitation: musculoskeletal disorders, pain, and rehabilitation. 4th ed. Philadelphia: WB Saunders; 2002. p. 640-6.

10. Bonica JJ, Sola AF. Chest pain caused by other disorders. In: Bonica JJ, editor. The management of pain. Vol 2 . Philadelphia: Lea \&Febiger; 1990. p. 1114-45.

11. Freeston J, Karim Z, Lindsay K, Gough A. Can early diagnosis and management of costochondritis reduce acute chest pain admissions? J Rheumatol 2004;31:2269-71.

12. Disla E, Rhim HR, Reddy A, Karten I, Taranta A. Costochondritis. A prospective analysis in an emergency department setting. Arch Intern Med 1994;154:2466-9. 
13. Guglielmi G, Cascavilla A, Scalzo G, Salaffi F, Grassi W. Imaging of sternocostoclavicular joint in spondyloarthropaties and other rheumatic conditions. Clin Exp Rheumatol 2009;27:402-8.

14. Yang W, Bahk YW, Chung SK, Choi K, Jo K, Jee MK. Pinhole skeletal scintigraphic manifestations of Tietze's disease. Eur J Nucl Med 1994;21:947-52.

15. Mathew AS, El-Haddad G, Lilien DL, Takalkar AM. Costosternal chondrodynia simulating recurrent breast cancer unveiled by FDG PET. Clin Nucl Med 2008;33:330-2.

16. Yucel M. Differential diagnosis and our treatment modalities in the sternoclavicular joint diseases. Acta Orthop Traumatol Turc 2006;28:21-4.

17. Rumball JS, Lebrun CM, Di Ciacca SR, Orlando K. Rowing injuries. Sports Med 2005;35:537-55.

18. Zaruba RA, Wilson E. Impairment based examination and treatment of costochondrotis: a case series. Int J Sports Phys Ther 2017;12:458-67.

19. Imamura ST, Imamura M. Sindrome de Tietze. In: Cossermelli W, editor. Terapeutica Em Reumatologia. Sao Paulo: Lemos Editorial; 2000. p. 773-7.

20. Senturk E, Sahin E, Serter S. Prolotherapy: An effective therapy for Tietze syndrome. J Back Musculoskelet Rehabil 2017;30:975-8.

21. Habib GS. Systemic effects of intra-articular corticosteroids. Clin Rheumatol 2009;28:749-56.

22. Habib G, Zahran R, Najjar R, Badarny S, Jabbour A, Artul $\mathrm{S}$, et al. The effect of intra-articular injection of Diprospan at the knee joint on the hypothalamic-pituitary-adrenal axis. Swiss Med Wkly 2015;145:w14134.

23. Wittich CM, Ficalora RD, Mason TG, Beckman TJ. Musculoskeletal injection. Mayo Clin Proc 2009;84:831-6.

24. Bellamy N, Campbell J, Robinson V, Gee T, Bourne R, Wells G. Intraarticular corticosteroid for treatment of osteoarthritis of the knee. Cochrane Database Syst Rev 2006;(2):CD005328.
25. Stephens MB, Beutler AI, O'Connor FG. Musculoskeletal injections: A review of the evidence. Am Fam Physician 2008;78:971-6.

26. Furtado RNV, Machado FS, Luz KRD, Santos MFD, Konai MS, Lopes RV, et al. Intra-articular injection with triamcinolone hexacetonide in patients with rheumatoid arthritis: Prospective assessment of goniometry and joint inflammation parameters. Rev Bras Reumatol Engl Ed 2017;57:115-21.

27. Arroll B, Goodyear-Smith F. Corticosteroid injections for osteoarthritis of the knee: Meta-analysis. BMJ 2004;328:869.

28. Ugur M, Tuguc A, Melikoglu MA, Yıldırım K, Senel K. A comparison of the effects of intraarticular hyaluronic acid and intraarticular methyl prednisolone acetate on patients with knee osteoarthritis. Eurasian J Med 2007;39:185-8.

29. Kamel M, Kotob H. Ultrasonographic assessment of local steroid injection in Tietze's syndrome. $\mathrm{Br} \mathrm{J}$ Rheumatol 1997;36:547-50.

30. Gologorsky R, Hornik B, Velotta J. Surgical management of medically refractory Tietze syndrome. Ann Thorac Surg 2017;104:e443-e445.

31. Deyle GD, Allen CS, Allison SC, Gill NW, Hando BR, Petersen EJ, et al. Physical therapy versus glucocorticoid injection for osteoarthritis of the knee. $\mathrm{N}$ Engl $\mathrm{J}$ Med 2020;382:1420-9.

32. Yetim Durgun T, Yetim I, Duru M. Investigation of the effect of intercostal blockade in palliation of pain in patients with rib fracture. Turk Gogus Kalp Dama 2012;20:287-90.

33. Barber DA, Harris SR. Oxygen free radicals and antioxidants: A review. Am Pharm 1994;NS34:26-35.

34. Aslan A, Aydoğan NH, İlhan M, Özerdemoğlu RA, Altuntaş İ, Yorgancigil H. The effect of different intraarticular drug applications to the antioxidation system and lipid peroxidation in gonarthrosis. Eur $\mathrm{J}$ Ther 2012;18:1-6. 


\section{Appendix 1}

Ağrı Derecelendirme Ölçeği (İngiliz Ağrı Derneği) (Türkçe versiyonu)

Pain Rating Scale (The British Pain Society) (Turkish version)

Başlık :

Ad1 :

Soyad1 :
Tarih

Hasta numarası :

Klinik

Lütfen ağrınızın şiddetini belirtmek için aşağıdaki ölçeği işaretleyin.

Sıfır (0) hiç ağrı olmaması, on (10) ise ağrının çok şiddetli olması anlamına gelir.

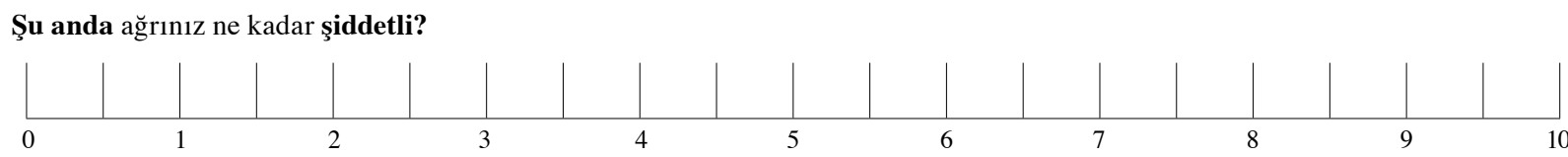

Hiç a ğrı yoktu

Ağrı çok şiddetliydi

Geçen hafta ağrınız ortalama olarak ne kadar şiddetliydi?

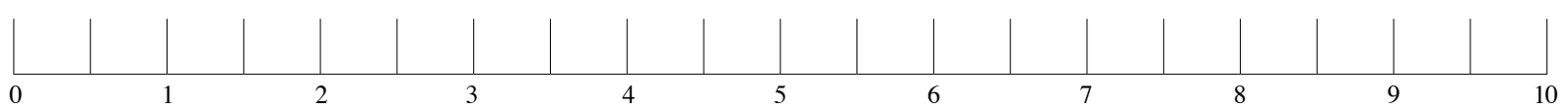

Hiç a ğrı yoktu

Ağrı çok şiddetliydi

Lütfen şimdi aynı yöntemi kullanarak ağrınızın size ne kadar sıkıntı verdiğini belirtin.

Şu anda ağrınız size ne kadar sıkıntı vermekte?

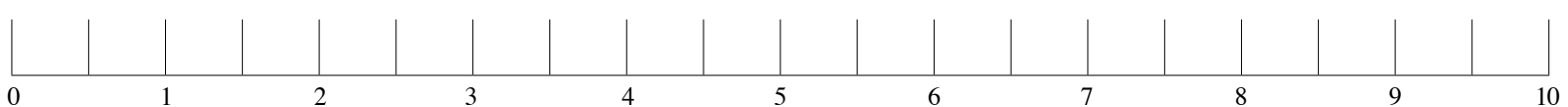

Hiç sıkıntı vermiyor

Çok fazla sıkıntı veriyor

Geçen hafta ağrınız ortalama olarak size ne kadar sıkıntı vermekteydi?

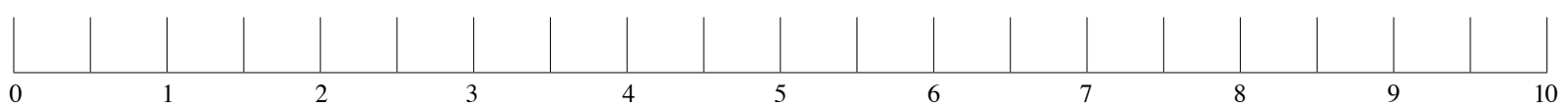

Hiç sıkıntı vermiyor

Çok fazla sıkıntı veriyordu

Lütfen şimdi aynı yöntemi kullanarak ağrınızın günlük faaliyetlerinizi ne ölçüde etkilediğini belirtin.

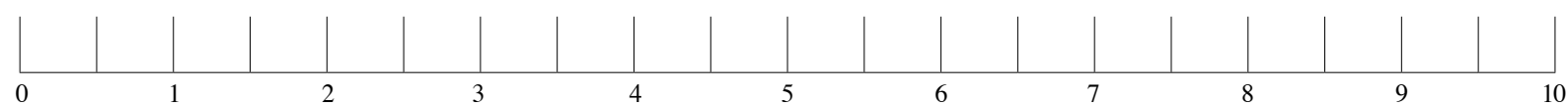

Hiç etkilenmiyor

Tamamen etkileniyor

Ağrınız için tedavi gördüyseniz bu tedavi ağrınızı ne ölçüde giderdi?

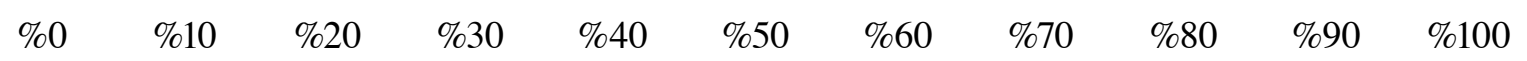

Hiç gidermedi

Tamamen giderdi 